\title{
GROWTH PERFORMANCES AND BACTERIAL LOAD OF HETEROPNEUSTES FOSSILIS (BLOCH, 1794) USING CINNAMON AS FEED SUPPLEMENT
}

\author{
Mst. Khadiza Begum, Md. Mostavi Enan Eshik, Nusrat Jahan Punom, \\ Md. Minhazul Abedin and Mohammad Shamsur Rahman* \\ Department of Fisheries, University of Dhaka, Dhaka-1000, Bangladesh
}

\begin{abstract}
Cinnamon has different biological properties such as antioxidant, antimicrobial, antidiabetic and antiallergic. This study was carried out to investigate the effect of cinnamon as feed supplement on growth performances and bacterial load of Heteropneustes fossilis. Twenty fries were stocked in each 60 litre aquarium for a rearing period of 90 days. Commercial diet was used that contains $0.0 \%$ (control), $0.5 \%$, and $1.0 \%$ cinnamon bark powder. The diet containing $1 \%$ cinnamon resulted in greater ADG, SGR, FCR and survival rate. Whereas, the diet containing $0.5 \%$ cinnamon resulted in greater condition factor and lower FCR. In most of the cases the diet containing 1\% cinnamon showed lower amount of bacterial count than the controlled condition. Cinnamon could have an antibacterial activity antagonistic to Vibrio and Aeromonas as there was no count found in fish flesh samples after 90 days of culture. The findings of this study suggest that growth performances and bacterial load of $H$. fossilis were better in commercial feed containing cinnamon powder. It is recommended that fish farmers can use cinnamon as feed supplement to improve growth performance and reduce bacterial load during culture of $H$. fossilis.
\end{abstract}

Key words: Heteropneustes fossilis, cinnamon, growth performance, bacterial load

\section{INTRODUCTION}

Stinging catfish, Heteropneustes fossilis (Bloch 1794) is an air-breathing catfish and commonly known as Shing mach in Bangladesh (http://en.bdfish. org/2011/09/stinging-catfish-heteropneustes-fossilis-bloch-1794/ accessed on 13 October 2018). This species is very popular for its delicious taste and high nutritional and medicinal value (Chakraborty and Nur 2012). It remains high amount of iron and fairly high content of calcium compared to many other freshwater fishes (Saha and Guha 1939). It is considered as a valuable food fish species and recommended as diet for the sick and convalescents. Being a lean fish it is very suitable for people for whom animal fats are undesirable (Rahman et al. 1982). It is an indigenous fish species and inhabits open water system of floodplains, canals, beel and haors of Bangladesh. But due to over exploitation and ecological changes in its natural habitats; this species may be threatened (http://www.iucnredlist.org/details/166452/0 accessed on 13 October 2018).

*Author for correspondence: <shamsur@du.ac.bd>

(C) 2018 Zoological Society of Bangladesh DOI: http://dx.doi.org/10.3329/bjz.v46i2.39049 
This fish has potential for aquaculture and it could be easily farmed in ponds and small ditches. In recent years, fish farming has been consolidating and occupying greater space in both national and international markets. Among freshwater fish species, $H$. fossilis stands out for its flesh quality, hardiness and faster growth during intensive farming. It is essential to develop suitable culture system for $H$. fossilis using best quality balanced diet for better production. Feed additives are edible substances that are added to animal feeds in small quantity to enhance the feed quality so that it enhances growth performance, feed utilization and reduces mortality in fish (Dada 2015). Several studies revealed that spices and medicinal plants can be used as feed additive in aquaculture for better growth and survival and microbial disease treatment as well (Immanuel et al. 2004). Usually spices are added to different types of food to impart flavor as well as to improve storage stability. Cinnamon has been using worldwide as a flavoring spice. Ahmad et al. (2011) reported that the diet containing 1\% cinnamon powder resulted in significantly greater $(\mathrm{p}<0.05)$ specific growth rate (SGR), feed conversion ratio (FCR), feed efficiency ratio (FER), protein efficiency ratio (PER), apparent protein utilization (APU), and energy utilization (EU). Setiawati et al. (2016) observed that the addition of cinnamon leaf extract and powder significantly increased the fish specific growth rate, feed efficiency, protein retention as compared to the control. Among its proven biological activities, several reports highlighted its antimicrobial activity (Singh et al. 2007 and Starliper et al. 2015), primarily attributable to cinnamaldehyde present in the bark of the plant (Wong et al. 2014). Cinnamon possesses various biological properties such as antioxidant, antimicrobial, antidiabetic and antiallergic. Main component of cinnamon bark oil is cinnamaldehyde which have strong antibacterial activity against nine strains of bacteria including Escherichia coli, Pseudomonas aeruginosa, Enterococcus faecalis, Staphylococcus aureus, Staphylococcus epidermidis, Klebsiella pneumonia, Salmonella species and Vibrio parahaemolyticus (Chang et al. 2001).

The overall objective of the proposed study was to investigate the effect of cinnamon on growth performances and to control bacterial load of $H$. fossilis. The specific objectives were: preparation of commercial feed with different percentage of cinnamon, culture of experimental fish, determination of growth performance parameters such as ADG, SGR, FCR, condition factor and survival rate and determination of bacterial load in experimental fish species.

\section{MATERIAL AND METHODS}

The cinnamon barks used were obtained from super market, then dried in an oven at $60^{\circ} \mathrm{C}$. Dried barks were grinded and sieved to produce cinnamon powder. 
Isocaloric commercial diet was obtained from fish feed industry. This feed was treated by the addition of cinnamon bark powder at 0, 0.5 and 1\% (Ahmad et al. 2011). The experiment was performed as- treatment 1 (T1/Control): commercial feed $+0 \%$ cinnamon powder, treatment 2 (T2): commercial feed + $0.5 \%$ cinnamon powder and treatment 3 (T3): commercial feed $+1 \%$ cinnamon powder.

Fry of $H$. fossilis $(9.91 \pm 0.258 \mathrm{~cm}$ and $6.176 \pm 0.218 \mathrm{~g})$ were collected from Reliance Aquafarm, Mymensingh. The rearing of $H$. fossilis was conducted for 90 days (March to June, 2017). The experiment was designed as above mentioned three treatments in three replication of each. The fry were randomly distributed at a rate of 20 fry per aquarium. Feeding was done twice daily at $8 \%$ of the average body weight for first 30 days, then $5 \%$ for next 30 days, after that, $2 \%$ for remaining 30 days. Each ration was divided into two equal parts, one portion was offered at 9.00 a.m. while the other at $4.00 \mathrm{p} . \mathrm{m}$. Water from each aquarium was exchanged at three days interval for the removal of uneaten feed and faeces. The aquarium was also cleaned per week and clean water was supplied in each of the aquariums. Physico-chemical parameters of water such as temperature, dissolve oxygen (DO) and $\mathrm{pH}$ were recorded twice in a week using mercury thermometer, DO meter (HANNA, HI-9146, USA), pH meter (HANNA, HI-8424, USA), respectively. Sampling was done each 15 days to determine the individual length and weight of the fish and data were recorded. Water samples of each treatment were tested for bacterial load at 15 days interval. At the end, the fish was fasted for $24 \mathrm{hrs}$, then counted and final length and weight was measured. At that time the bacterial loads of fish samples were determined.

Fish growth performance: Fish growth performance was calculated using the following formulae:

a. Average Daily Gain $(\mathrm{ADG}, \mathrm{g} /$ day $)=($ Mean final weight - mean initial weight $)$ /time interval.

b. Specific Growth Rate $(\mathrm{SGR})=\left\{\left(\log _{\mathrm{e}}\right.\right.$ final weight $-\log _{\mathrm{e}}$ initial weight $) /$ time interval $\times 100$.

c. Feed Conversion Ratio $(\mathrm{FCR})=$ Feed consumed/weight gain .

d. Condition factor, $\mathrm{K}=\mathrm{W} / \mathrm{L}^{3} \times 100$ where, $\mathrm{K}=$ Condition factor, $\mathrm{W}=$ Body weight in grams and $\mathrm{L}=$ Body length in $\mathrm{cm}$.

e. Survival Rate $(\%)=$ Number of fry that survived/Total no. of fry stocked $x$ 100.

According to Punom et al. (2016) bacterial load was determined for total bacterial count (TBC), total Vibrio count, total Salmonella-Shigella count, total Staphylococcal count and total Aeromonas count on nutrient agar, TCBS media, 
SS agar, Manitol Salt Agar (MSA) and Aeromonas agar plate, respectively. For bacterial counts $1 \mathrm{~g}$ of each sample was homogenized with $9 \mathrm{ml}$ physiological saline. Then $100 \mu \mathrm{l}$ of sample solution was diluted with $900 \mu \mathrm{l}$ sterile physiological saline and further diluted up to $10^{-5}$ for inoculating on agar media. Then $100 \mu \mathrm{l}$ of each homogenized diluted subsample was inoculated on agar plates and incubated at $37^{\circ} \mathrm{C}$ for $24 \mathrm{hrs}$ in incubator (WTB Binder, Germany). After $24 \mathrm{~h}$ of incubation, the plates having well discrete colonies were selected for counting. The plates were counted as cfu/g of sampled fish.

Statistical analysis: Data were analyzed by using one-way ANOVA followed by Tukey's HSD post hoc for multiple comparisons. The data were presented as mean \pm SEM and evaluated by using the statistical package of SPSS (version 20.0) with the level of significance at $p<0.05$. Microsoft office excel (2013) was used to plot graph.

\section{RESULTS AND DISCUSSION}

The present study described the growth performance and the bacterial density of Stinging catfish fed with commercial feed with $0,0.5$ and $1 \%$ cinnamon powder.

Water quality parameters for culturing $H$. fossilis: In the study for rearing $H$. fossilis fry dissolved oxygen, $\mathrm{pH}$ and temperature that were recorded are provided in Table 1.

Table 1. Water quality parameters in three treatments during the study period

\begin{tabular}{lccc}
\hline \multirow{2}{*}{ Parameter } & \multicolumn{3}{c}{ Three treatments } \\
\cline { 2 - 4 } & $\begin{array}{c}\text { Commercial feed } \\
\text { (Control/T1) }\end{array}$ & $\begin{array}{c}\text { Commercial feed+ } \\
\text { 0.5\% cinnamon (T2) }\end{array}$ & $\begin{array}{c}\text { Commercial feed+1\% } \\
\text { cinnamon (T3) }\end{array}$ \\
\hline Dissolved oxygen (DO) $(\mathrm{mg} / \mathrm{l})$ & $2.31 \pm 0.77$ & $1.91 \pm 0.48$ & $1.27 \pm 0.60$ \\
$\mathrm{pH}$ & $7.31 \pm 0.18$ & $7.24 \pm 0.1$ & $7.29 \pm 0.13$ \\
Temperature $\left({ }^{\circ} \mathrm{C}\right)$ & $28.05 \pm 0.51$ & $27.98 \pm 0.3$ & $28.08 \pm 0.53$ \\
\hline
\end{tabular}

Water quality parameter in the rearing aquarium of $H$. fossilis in this experiment varied with the type of diet applied but did not show any negative effect on fish. No significant differences were observed on temperature, $\mathrm{pH}$ and dissolved oxygen (DO). Ahmad et al. (2011) evaluated the effect of cinnamon (Cinnamomum zeylanicum) on growth performance, feed utilization, whole-body composition and resistance to Aeromonas hydrophila in Nile Tilapia and they found, water temperature ranged between $26-29^{\circ} \mathrm{C}$, dissolved oxygen (DO) ranged between 4.5 - $5.5 \mathrm{mg} / \mathrm{l}$, $\mathrm{pH}$ ranged between 7.6 - 8.0. 


\section{Growth performances of Heteropneustes fossilis}

The highest condition factor was found in T2 $(0.66 \pm 0.22 \%)$ fed with commercial feed with $0.5 \%$ cinnamon powder and the lowest was in T1 $0.65 \pm$ $0.04 \%)$ fed with commercial feed (Fig. 1). On 90th day, comparatively higher value $(0.66 \pm 0.22 \%)$ was found in commercial feed with $0.5 \%$ cinnamon powder than commercial feed containing $0 \%$ cinnamon and $1 \%$ cinnamon powder.

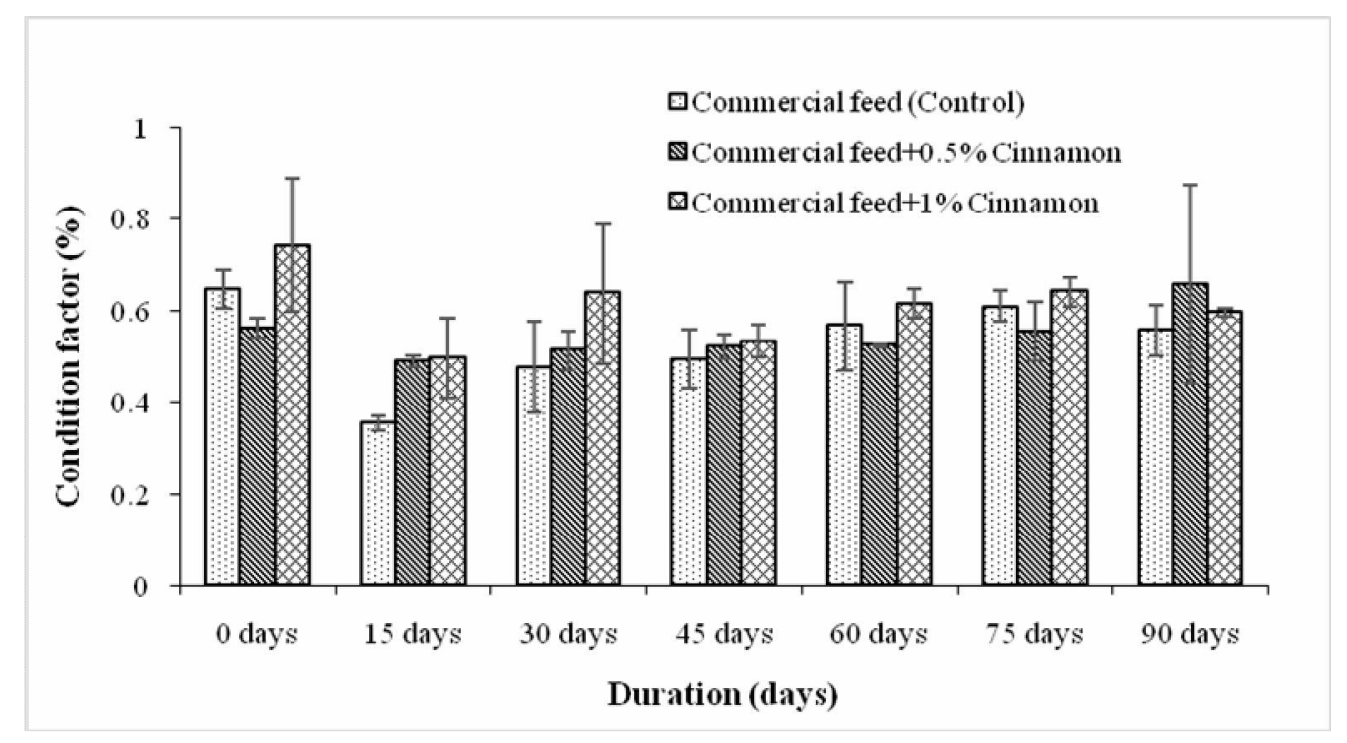

Fig. 1. Condition factor (\%) of $H$. fossilis at 90 days rearing period. Bars (Mean \pm SEM) with no superscripts are not significant within group (ANOVA, $\mathrm{p}>0.05$ ).

Rahman et al. (1997) in a study on the survival and growth of cat fish giving selected supplemental feeds got the values of condition factor between 0.81 and 0.87. Ahmad et al. (2011) evaluated the effect of cinnamon on growth performance in Nile Tilapia and they used $0 \%$ (control), 0.5, 1 and 1.5\% of cinnamon powder and recorded $\mathrm{K}$ factor were $1.59 \pm 0.02,1.52 \pm 0.05,1.67 \pm$ 0.01 and $1.47 \pm 0.02$, respectively.

Fig. 2 represented the highest ADG of shing fry which was found in T3 $(0.097 \pm 0.03 \mathrm{~g} /$ day) and the lowest was in $\mathrm{T} 1(0.079 \pm 0.007 \mathrm{~g} /$ day). The ADG value of T3 was higher than T1. On 45th day, ADG of fish was higher in T2 0.13 $\pm 0.038 \mathrm{~g}$ /day), however, on 60th day, the value was higher in T3 $(0.11 \pm 0.016$ g/day) compared to $\mathrm{T} 1$ and $\mathrm{T} 2$. No significant difference was observed between the three different rearing conditions. 


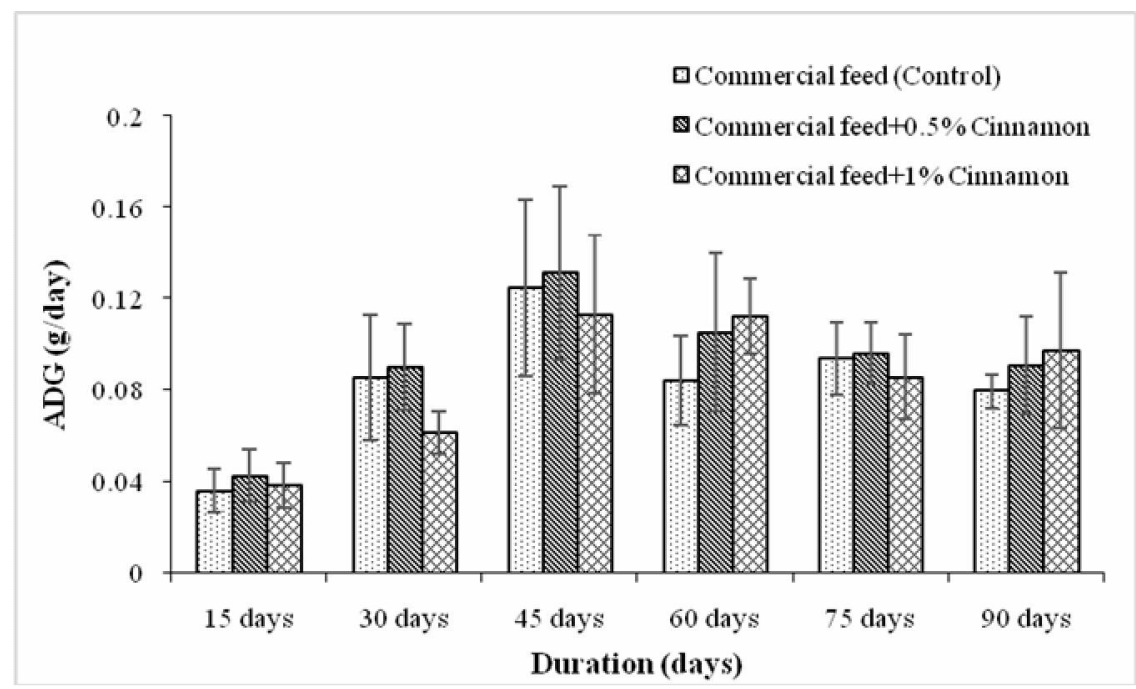

Fig. 2. Average daily gain (g/day) of $H$. fossilis at 90 days rearing period. Bars (Mean $\pm \mathrm{SEM}$ ) with no superscripts are not significant within group (ANOVA, $p>0.05$ ).

The highest specific growth rate of shing fry was found in T3 $(0.73 \pm 0.25 \%)$ and the lowest was in $\mathrm{T} 1(0.63 \pm 0.05 \%)$. On $90^{\text {th }}$ day specific growth rate was not significantly different in three rearing conditions.

Setiawati et al. (2016) evaluated the growth performance of Asian catfish (Pangasianodon hypophthalmus) fed with diets containing Cinnamomum burmannii leaf powder and extract. They recorded highest SGR $(1.18 \pm 0.05 \%)$ in fish fed with diet containing $1 \%$ cinnamon leaf powder for 60 days. Ahmad et al. (2011) found that the fish fed the diet containing 1\% cinnamon showed the highest average body weight, weight gain percentage, and SGR in comparison with other diets.

Fish, that were fed on commercial feed $(3.07 \pm 0.29)$ exhibited lowest feed conversion ratio (FCR) than those fed with commercial feed $+0.5 \%$ cinnamon powder $(3.18 \pm 0.63)$ and commercial feed $+1 \%$ cinnamon powder $(3.66 \pm 1.59)$. On $90^{\text {th }}$ day feed conversion ratio did not differ significantly (ANOVA, $p>0.05$ ) (Fig. 4). For fish fed well prepared diets, FCR values below 1 have been reported, although generally it ranges between 1.2 and 1.5 (De Silva and Anderson 1995). Ahmad et al. (2011) used 0\% (control), 0.5, 1 and 1.5\% of cinnamon powder to rear Nile tilapia and recorded the FCR values $2.21 \pm 0.022,2.05 \pm 0.015,1.95 \pm$ $0.01,1.94 \pm 0.01$, respectively. 


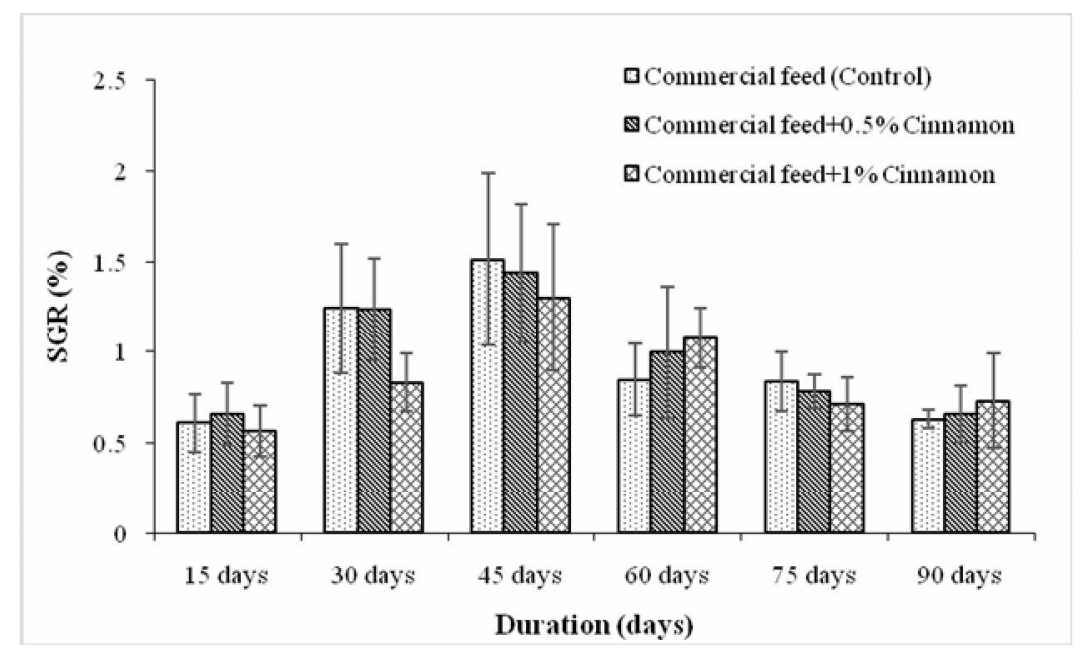

Fig. 3. Specific growth rate (\%) of $H$. fossilis at 90 days rearing period. Bars (Mean \pm SEM) with no superscripts are not significant within group (ANOVA, $p>0.05$ ).

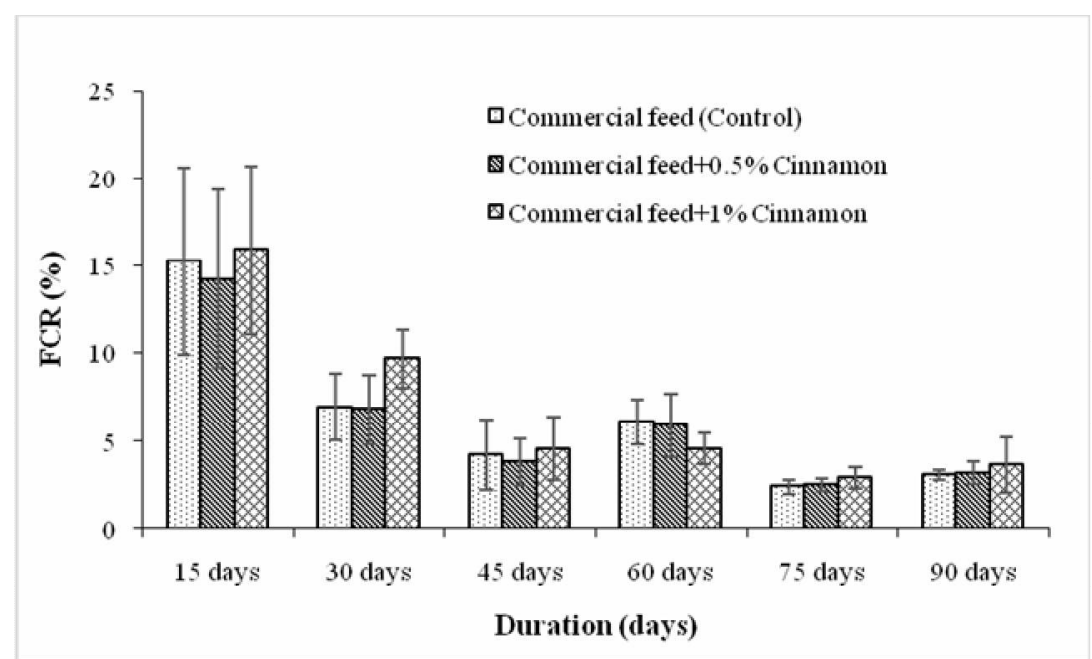

Fig. 4. Feed conversion ratio (FCR) (\%) of $H$. fossilis at 90 days rearing period. Bars (Mean $\pm \mathrm{SEM}$ ) with no superscripts are not significant within group (ANOVA, $p>0.05$ ).

After culture period, Fig. 5 presented here the survival rates of shing fry in T1, T2 and T3 were (92 $\pm 0.58 \%),(94.68 \pm 0.33 \%)$ and $(97.32 \pm 0.33 \%)$, respectively.

Setiawati et al. (2016) recorded 100\% survival rate for all treatments during 60 days of maintenance while studying the growth performance of Pangasianodon hypophthalmus fed diets containing Cinnamomum burmannii leaf either in powder or extract form at different doses like $0.1 \%$ cinnamon leaf extract and 1\% cinnamon leaf powder. 


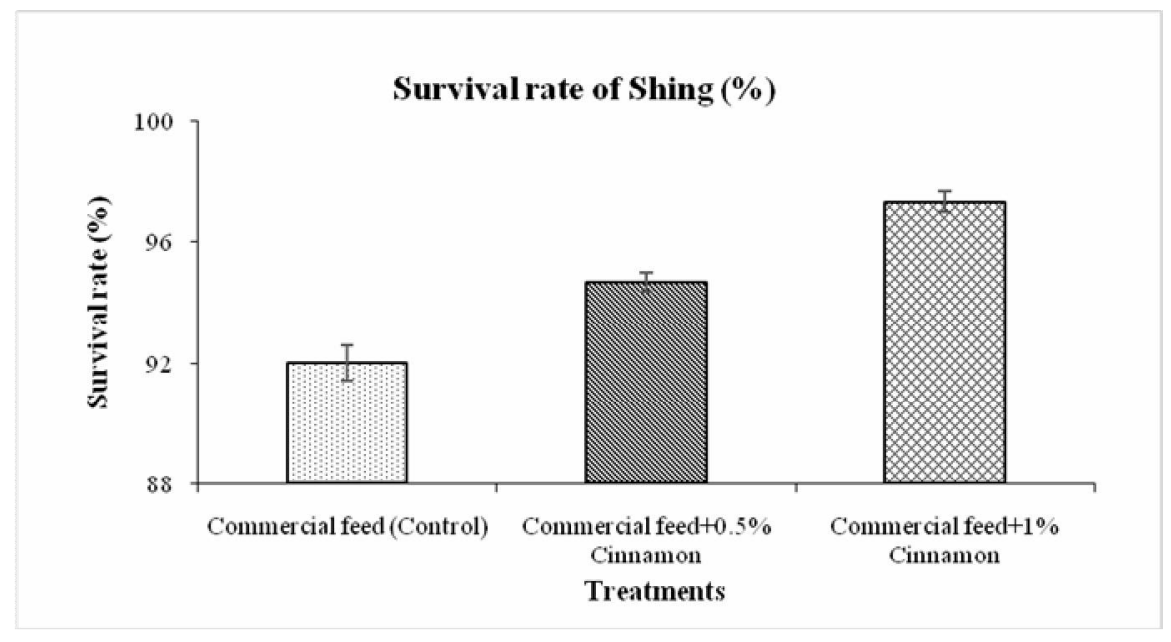

Fig. 5. Survival rate (\%) of $H$. fossilis at 90 days rearing period. Bars (Mean \pm SEM) with no superscripts are not significant within group (ANOVA, $\mathrm{p}>0.05$ ).

\section{Bacterial density of water and shing sample on different rearing conditions}

Bacterial count of water samples: Results of the quantitative estimation of total bacteria, total Vibrio, total Salmonella-Shigella, total Aeromonas and total Staphylococcal count for water samples of three different treatment at different rearing periods are demonstrated in Table 2 . On $15^{\text {th }}$ day, the highest total bacterial density of water samples was $1.67 \pm 0.41 \times 10^{5} \mathrm{cfu} / \mathrm{g}$ in T2. On $75^{\text {th }}$ day, the lowest total bacterial density of water sample was found in $\mathrm{T} 1$ which was $2.75 \pm 1.61 \times 10^{3} \mathrm{cfu} / \mathrm{g}$. Significant difference was found; in between T2 and T3 at 60 days of rearing period, between $\mathrm{T} 1$ and $\mathrm{T} 2$ at 75 days of rearing period. The highest Salmonella-Shigella count was $6.18 \pm 0.82 \times 10^{4} \mathrm{cfu} / \mathrm{g}$ in T2 on $15^{\text {th }}$ day, however, on $90^{\text {th }}$ day, the lowest value was $0.60 \pm 0.50 \times 10^{2} \mathrm{cfu} / \mathrm{g}$ in T3. On $45^{\text {th }}$ day, the highest total Staphylococcal count was evaluated in T1 and that was $6.3 \pm 5.6 \times 10^{4} \mathrm{cfu} / \mathrm{g}$ but on the $60^{\text {th }}$ day the lowest density was $0.03 \pm$ $0.03 \times 10^{2}$ in T3. However, for water samples, total Aeromonas count from $75^{\text {th }}$ to $90^{\text {th }}$ day rearing period was zero. On $45^{\text {th }}$ day, Vibrio count was significantly different ( $<<0.05$ ) between T1 and T2, T1 and T3. But no Vibrio was observed at 90 days of rearing period. Therefore, it can be said that cinnamon might have antibacterial activity as in most of the cases the lowest bacterial load was found T3 which was treated with commercial feed with $1 \%$ cinnamon. It can also be said that the antibacterial activity is effective after a certain period of time since in this study it was observed that Salmonella-Shigella count was lowest on $90^{\text {th }}$ day of rearing whereas at that time Aeromonas and Vibrio count was zero. 


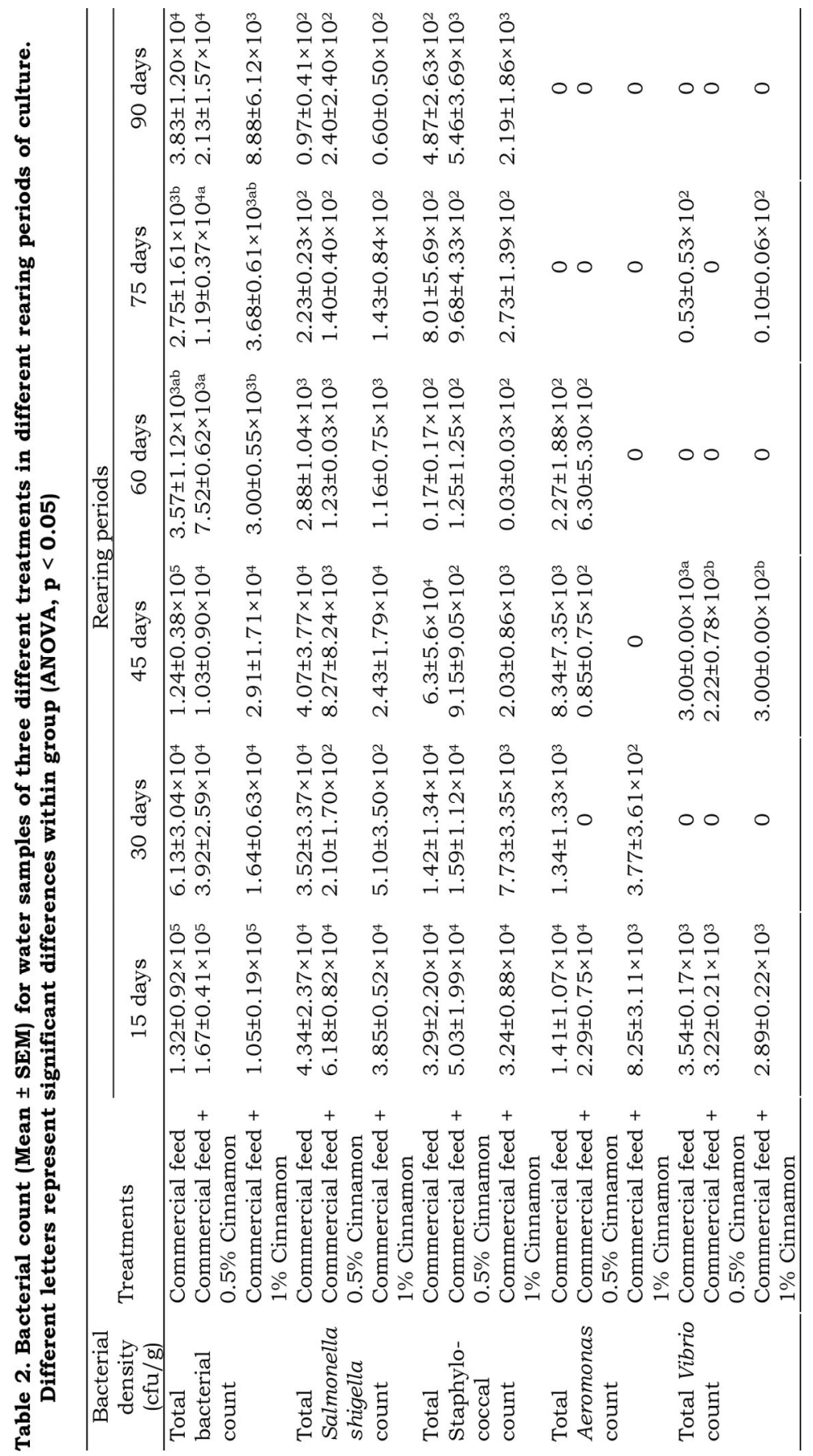


Bacterial count of fish samples: The highest total bacterial density of fish samples was quantified on T2 $\left(1.14 \pm 1.05 \times 10^{5} \mathrm{cfu} / \mathrm{g}\right)$, where the lowest total bacterial count was defined from T1 $\left(8.39 \pm 3.96 \times 10^{4} \mathrm{cfu} / \mathrm{g}\right)$. Maximum total Salmonella-Shigella count $\left(1.2 \pm 1.2 \times 10^{3} \mathrm{cfu} / \mathrm{g}\right)$ was evaluated from T1 where fish were fed with commercial feed. The minimum total Salmonella-Shigella count was evaluated from T2 (commercial feed $+0.5 \%$ cinnamon powder) and counted density was $1.17 \pm 0.73 \times 10^{2} \mathrm{cfu} / \mathrm{g}$.

Table 3. Bacterial count (Mean \pm SEM) for fish samples of three different treatments after 90 days of culture (ANOVA, $p>0.05$ )

\begin{tabular}{lccc}
\hline \multirow{2}{*}{ Bacterial density (cfu/g) } & \multicolumn{3}{c}{ Treatments } \\
\cline { 2 - 4 } & $\begin{array}{c}\text { Commercial feed } \\
\text { (Control) }\end{array}$ & $\begin{array}{c}\text { Commercial feed }+ \\
0.5 \% \text { cinnamon }\end{array}$ & $\begin{array}{c}\text { Commercial feed + } \\
1 \% \text { cinnamon }\end{array}$ \\
\hline Total bacterial count & $8.39 \pm 3.96 \times 10^{4}$ & $1.14 \pm 1.05 \times 10^{5}$ & $1.1 \pm 0.32 \times 10^{5}$ \\
Total Salmonella-Shigella count & $1.2 \pm 1.2 \times 10^{3}$ & $1.17 \pm 0.73 \times 10^{2}$ & $3.33 \pm 2.84 \times 10^{2}$ \\
Total Staphylococcal count & $5.57 \pm 2.75 \times 10^{4}$ & $3.12 \pm 2.78 \times 10^{4}$ & $4.73 \pm 2.83 \times 10^{4}$ \\
Total Aeromonas count & 0 & 0 & 0 \\
Total Vibrio count & 0 & 0 & 0 \\
\hline
\end{tabular}

Accordingly, the highest total Staphylococcal count was evaluated from T1 $\left(5.57 \pm 2.8 \times 10^{4} \mathrm{cfu} / \mathrm{g}\right)$ and lowest count was found from T2 $\left(3.12 \pm 2.8 \times 10^{4}\right.$ $\mathrm{cfu} / \mathrm{g})$. No total Aeromonas and total Vibrio count was obtained from the fish muscle samples of any treatment. No significant difference was observed among all bacterial count.

According to ICMSF (1986) guideline, acceptable limit of total bacterial counts for giant prawns and white fish are $10^{6}$ and $5 \times 10^{5} \mathrm{cfu} / \mathrm{g}$, respectively. In this study, total bacterial count was within the acceptable limit. It was also determined from this study that total bacterial density was lower for cinnamon mixed diet than the commercial diet. The limit of harmful and pathogenic microorganisms, such as Salmonella spp., Shigella spp. is $0 \mathrm{cfu} / \mathrm{g}$ and $1.0 \times 10^{2}$ $\mathrm{cfu} / \mathrm{g}$, respectively (ICMSF 1986). Salmonella, Shigella are not usually found as these are not the normal flora of fishes or of their environment (Huss et al. 2003). In the present study the value is slightly higher than the limit. Therefore it can be said that the supplied water and supplied feed were not good enough to maintain the health of fish. A considerable amount of Staphylococcus spp. found in water and fish type of experimented sample. According to ICMSF (1986) the suggested limit for Staphylococcus spp. is $>10^{3} \mathrm{cfu} / \mathrm{g}$ which confirms the contagion of the experimental samples with Staphylococcus. In the present study, maximum total Aeromonas count was quantified from water samples but nothing found from the fish samples. The use of cinnamon could enhance the 
innate immune system of fish, allowing a better response to stressful environmental conditions (Rattanachaikunsopon and Phumkhachorn 2010). Cinnamon had an antibacterial activity antagonistic to pathogenic A. hydrophila (GMF 2007). Abdel-Wahab et al. (2007) found that 0.5\% cinnamon level in the diet is enough to eliminate harmful microbes in the gut, improve food absorption, and control blood sugar to a certain extent. According to ICMSF (1986), fresh and frozen fish should be free of Vibrio (0 cfu/g). The present study revealed that microbial quality of fish were acceptable in order of absence of Vibrio in fish samples. Arancibia et al. (2014) observed the antibacterial effect of cinnamon essential oil on Vibrio parahaemolyticus and proved that the release of cinnamon essential oil from polysaccharide bilayer films was effective for $V$. parahaemolyticus inhibition in chilled shrimps.

\section{CONCLUSION}

Feed enrichment with 0.5 and $1 \%$ powder of cinnamon bark was efficient and applicable in improving the growth performance of stinging catfish with increasing specific growth rate, feed conversion ratio and survival rate. Fish feed supplied with cinnamon powder as a feed additive may improve the health status and growth performances of $H$. fossilis as this study recorded bacterial load was comparatively lower in the culture conditions supplied with cinnamon mixed commercial feed.

\section{LITERATURE CITED}

ABDEL-WAHAB, A.M., HASSOUNA, M.M.E., ABD EL-MAKSOUD, A.M.S., ABD EL TAWAB, A. and ABU-SEEF, A.M.M. 2007. Cinnamon as a feed supplemented in Nile tilapia (Oreochromis niloticus) diets reared in earthen ponds. Egypt. J. Nutr. Feeds 10(2): 881-890.

AHMAD, M.H., EL MESALlAMY, A.M., SAMIR, F. and ZAHRAN, F. 2011. Effect of cinnamon (Cinnamomum zeylanicum) on growth performance, feed utilization, whole-body composition, and resistance to Aeromonas hydrophila in Nile tilapia. J. Appl. Aquaculture 23(4): 289-298.

ARANCIBIA, M., GIMÉNEZ, B., LÓPEZ-CABALLERO, M.E., GÓMEZ-GUILlÉN, M.C. and MONTERO, P. 2014. Release of cinnamon essential oil from polysaccharide bilayer films and its use for microbial growth inhibition in chilled shrimps. Food Sci. Technol. 59: 989-995.

CHAKRABORTY, B.K. and NUR, N.N. 2012. Growth and yield performance of shingi, Heteropneustes fossilis and koi, Anabas testudineus in Bangladesh under semi-intensive culture systems. Int. J. Agril. Res. Innov. \& Tech. 2 (2): 15-24.

CHANG, S.T., CHEN, P.F. and CHANG, S.C. 2001. Antibacterial activity of leaf essential oils and their constituents from Cinnamonmum osmophloem. J. Ethnopharmacology 77(1): 123-127.

DADA, A.A. 2015. Improvement of tilapia (Oreochromis niloticus Linnaeus, 1758) growth performance fed three commercial feed additives in diets. J. Aquac. Res. Dev. 6: 325-327.

DE SILVA, S.S. and ANDERSON, T.A. 1995. Fish nutrition in aquaculture. Chapman and Hall, London, 31 pp. 
HUSS, H.H., ABABOUCH, L. and GRAM, L. 2003. Assessment and management of seafood safety and quality. FAO Fisheries Technical Paper 444, Food and Agriculture Organization of the United Nations, Rome.

GMF (George Mateljan Foundation). 2007. The world's healthiest food. http://whfoods.org./

ICMSF (International Commission on Microbiological Specification for Foods). 1986. Microorganism in Food. In. Application of the Hazard Analysis Critical Control Point (HACCP) System to Ensure Microbiological Safety and Quality.2 ${ }^{\text {nd }}$ ed. Blackwell Scientific Publications. 42. pp: 181-195.

IMMANUEL, G., VINCYBAI, V.C., SIVARAM, V., PALAVESAM, A. and MARIAN, M.P. 2004. Effect of butanolic extracts from terrestrial herbs and seaweeds on the survival, growth and pathogen (Vibrio parahaemolyticus) load on shrimp Penaeus indicus juveniles. Aquaculture 236: 53-65.

PUNOM, N.J., HASAN, A.K.M.M., HAQUE, W., BEGUM, M.K. and RAHMAN, M.S. 2016. 16S rRNA sequence based identification of pathogenic gut microbiota of Rohu Labeo rohita (HamiltonBuchanan 1822) and Silver Carp Hypophthalmichthys molitrix (Valenciennes 1844). Dhaka Univ. J. Biol. Sci. 25(2): 169-184

RAHMAN, M.A., GHEYASUDDIN, H., RASID, M.H. and CHOUDHURY, M.F.Z. 1982. Proximate composition and native quality of freshwater Zeol fishes of Bangladesh. Bangladesh J. Fish. 25: 37-43.

RAHMAN, M.A., BHADRA, A., BEGUM, N. and HUSSAIN, M.G. 1997. Effects of some selective supplemental feeds on the survival and growth of catfish (Clarias batrachus Lin.) fry. Bangladesh. J. Fish. Res. 1: 55-58.

RATTANACHAIKUNSOPON, P. and PHUMKHACHORN, P.2010. Potential of cinnamon (Cinnamomum verum) oil to control Streptococcus iniae infection in tilapia (Oreochromis niloticus), Fish. Sci. 76: 287-293.

SAHA, K.C. and GUHA, B.C 1939. Nutritional investigation on Bengal fish. Indian J. Medical Res. 26: 921-927.

SETIAWATI, M., JUSADI, D., LAHENG, S., SUPRAYUDI, M.A. and VINASYIAM, A. 2016. The enhancement of growth performance and feed efficiency of Asian catfish, Pangasianodon hypophthalmus fed on Cinnamomum burmannii leaf powder and extract as nutritional supplementation. Aquac Aquar Conserv Legis (AACL Bioflux) 9(6): 1301-1309.

SINGH, G., MAURYA, S., DELAMPASONA M.P. AND CATALAN, C.A.N. 2007. A comparison of chemical, antioxidant and antimicrobial studies of cinnamon leaf and bark volatile oils, oleoresins and their constituents. Food Chem. Toxicol. 45:1650-1661.

STARLIPER, C.E., KETOlA, H.G., NOYES, A.D., SCHILl, W.B., HENSON, F.G. and CHALUPNICKI, M.A. 2015. Investigation of the bactericidal activity of selected essential oils to Aeromonas spp. J. Adv. Res. 6: 89-97.

WONG, Y.C., AHMAD-MUDZAGQIR, M.Y. and WAN-NURDIYANA, W.A. 2014. Extraction of essential oil from cinnamon (Cinnamomum zeylanicum). Orient. J. Chem. 30: 37-47. 